\title{
TRIPLE INOCULATION WITH BRADYRHIZOBIUM, GLOMUS AND PAENIBACILLUS ON COWPEA (VIGNA UNGUICULATA [L.] WALP.) DEVELOPMENT
}

\author{
André Suêldo Tavares de Lima, Terezinha Ferreira Xavier, Cláudia Elizabete Pereira de Lima*, José de Paula \\ Oliveira, Adália Cavalcanti do Espírito Santo Mergulhão, Márcia do Vale Barreto Figueiredo
}

\author{
Instituto Agronômico de Pernambuco, Recife, PE, Brasil
}

Submitted: October 04, 2010; Returned to authors for corrections: October 31, 2010; Approved: January 31, 2011.

\begin{abstract}
The use of microorganisms to improve the availability of nutrients to plants is of great importance to agriculture. This study aimed to evaluate the effect of triple inoculation of cowpea with arbuscular mycorrhizal fungi (AMF), plant growth-promoting bacteria (PGPB) and rhizobia to maximize biological nitrogen fixation (BNF) and promote plant growth. The experiment was conducted in a greenhouse using cowpea plants (Vigna unguiculata L. Walp cv. IPA 206). The treatments included inoculation with strains of Bradyrhizobium sp. (BR 3267 and EI - 6) individually and as a mixture, an absolute control (AC) and mineral nitrogen control (NC), all combined with the presence or absence of native AMF (Glomus

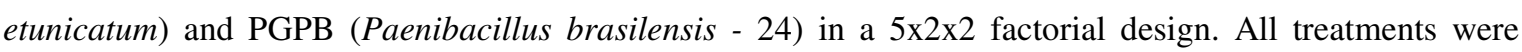
replicated three times. Contrasts were performed to study the treatment of variables. Inoculation with Bradyrhizobium sp. (BR 3267 and EI - 6) and G. etunicatum favored nitrogen acquisition and phosphorus availability for the cowpea plants. Inoculation with P. brasilensis - 24 increased colonization by Bradyrhizobium sp. and G. etunicatum and promoted cowpea growth, while the nitrogen from symbiosis was sufficient to supply the plants nutritional needs.
\end{abstract}

Key words: arbuscular mycorrhiza, biological nitrogen fixation, PGPB, rhizobia.

\section{INTRODUCTION}

Cowpea (Vigna unguiculata [L.] Walp.), a rustic grain legume adapted to the Northeast region of Brazil, is rich in nutrients. It is planted mainly by family farmers who sell their surplus production to generate extra income (25). However, the low productivity of this crop is linked to the low technological level used in its production, especially low water availability, seeds with low genetic quality and low use of inputs such as fertilizers and rhizobial inoculants (13).

The use of microorganisms to improve nutrient availability to plants is important for improved or even successful agriculture (12). Currently, there is an emerging demand to decrease dependence on chemical fertilizers and increase the sustainability of agriculture. Arbuscular mycorrhizal fungi (AMF), plant growth promoting bacteria 
(PGPB) and the association of rhizobia with leguminous plants are mutualistic symbioses of great economic importance to increase crop yields (3). AMF are obligatory biotrophs, only multiplying in metabolically active roots. Their hyphae can be compared to root extensions of the host plant; because they absorb water and nutrients and then supply them to the plant through ramifications formed by the hyphae inside the host's cells, called arbuscules (29).

Phosphorus (P), an element that is scarce and has low mobility in the soil, is an important nutrient supplied to plants through AMF (8). Biological nitrogen fixation (BNF) demands high amounts of ATP energy, so an adequate supply of phosphorous offered by AMF benefits nodule formation (6). Nitrogen is one of the most limiting nutrients to agricultural production in tropical regions of Brazil. Therefore, BNF has great economic and environmental importance for crop production (26). Rhizobia, when in symbiotic association with leguminous plants, convert atmospheric $\mathrm{N}_{2}$ to $\mathrm{NH}_{3}$, which is used by the plants in various ways. This association can be an alternative to chemical nitrogen fertilizers, with the advantage of being more economically viable and environmentally friendly (10).

Vessey (34) reported that plant growth promoting bacteria (PGPB) colonize different organs of plants and exert beneficial effects on them. These bacteria act indirectly by suppressing diseases and directly by producing or modifying phytohormone concentration, nitrogen fixation, solubilization of inorganic phosphate or other nutrients from the soil, sulfur oxidation, production of siderophores, and increasing root permeability (30). Thus, this study aimed to evaluate the effect of triple inoculation of cowpea plants with arbuscular mycorrhizal fungi (AMF), plant growth-promoting bacteria (PGPB) and rhizobia, seeking to maximize biological nitrogen fixation (BNF) and promote plant growth.

\section{MATERIALS AND METHODS}

The soil used in this experiment was classified as Yellow
Argisol (11) and was obtained from the Experimental Station of the Itapirema - Agronomic Institute of Pernambuco (IPA), located at latitude $07^{\circ} 34^{\prime} 00^{\prime \prime}$ and longitude $35^{\circ} 00^{\prime} 00^{\prime \prime}$. The soil was collected from the surface layer $(0-20 \mathrm{~cm})$. After air drying, it was sieved (2.0-mm mesh sieve) and homogenized. The native populations of rhizobia and Glomus etunicatum Becker and Gerdemann were also evaluated and were present at $1.5 \times 10^{3} \mathrm{UFC} \mathrm{mL}^{-1}$ and 9 glomerospores per $50 \mathrm{~g}$ of soil, respectively. The legume used was the cowpea (Vigna unguiculata [L.] Walp. cv. IPA-206) from the IPA Seed Laboratory. The seeds were disinfected by immersion in $70 \%$ alcohol for 30 seconds and $2 \%$ sodium hypochlorite for 1 minute and then were rinsed 7 times with sterile distilled water (35).

The strains of Bradyrhizobium sp. used were BR 3267 from the CNPAB (National Center for Research in Agrobiology (Seropédica - Rio de Janeiro, RJ- Brazil) and EI 6 from the IPA Soil Biology Laboratory, and a mixture of the strains (BR 3267 + EI - 6) grown separately. The bacteria (BR 3267 and EI - 6) were purified in YMA medium (agar, mannitol and yeast extract) using Congo red as an indicator (35). Afterwards, the strain was grown in duplicate $250-\mathrm{mL}$ Erlenmeyer flasks with YM medium (mannitol and yeast extract) using a rotator shaker at $28^{\circ} \mathrm{C}$ for 3 to 6 days, according to the bacterial growth. The strain of PGPR (Paenibacillus brasilensis - 24) used (isolated from maize rhizospheres from Cerrado soil) was provided by the Microbial Genetics Laboratory - Prof. Paulo de Góes Institute of Microbiology - Center for Health Sciences - Rio de Janeiro Federal Rural University (UFRJ). This strain was selected in previous experiments (22) and showed better symbiotic performance when co-inoculated with Bradyrhizobium sp. in cowpea plants. It was grown in duplicate 250-mL Erlenmeyer flasks with TSB medium (trypticase soy broth), using a rotator shaker at $28^{\circ} \mathrm{C}$ for 24 hours. The spores of G. etunicatum were expanded in pots containing vermiculite and sand (in 1:1 proportion, autoclaved for 1 hour at $120{ }^{\circ} \mathrm{C}$ and $101 \mathrm{kPa}$ ), with 
intervals of 24 hours for three consecutive days, using Panicum miliaceum as a host plant.

The experiment was conducted in a greenhouse at the IPA in 8$\mathrm{kg}$ pots with $6 \mathrm{~kg}$ of soil per pot. Seven cowpea seeds per pot were planted in each pot. At the time of sowing, each seed was inoculated with a mixture of $2 \mathrm{~mL}$ of the YM medium containing $10^{8} \mathrm{CFU} \mathrm{mL}$ of each strain of Bradyrhizobium sp., $2 \mathrm{~mL}$ of the TSB medium

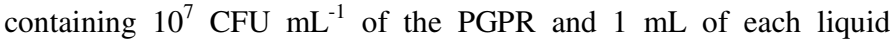
culture of strains of Bradyrhizobium sp. (BR 3267 and EI - 6). In the G. etunicatum inoculation, 120 spores were used per pot.

After thinning the cowpeas at seven days, two plants were kept in each pot. For every kilogram of soil, $2 \mathrm{~mL}$ of the nutrient solution of Hoagland and Arnon (17) without N and P was applied weekly. For the nitrogen treatment, ammonium sulfate was used at a concentration of $20 \mathrm{~kg} \mathrm{ha}^{-1}$, distributed in three applications: 10, 20 and 30 days after germination. All pots were irrigated with distilled water until reaching the pot capacity. The cowpeas were harvested 40 days after sowing. The following variables were evaluated: plant height at 10 , 20, 30 and 40 days after sowing, root length (RL), shoot dry matter (SDM), root dry matter (RDM), nodule dry matter (NDM), SDM/RDM ratio, nitrogen content by the Kjeldahl method according to Bremner (4), nitrogen accumulation (Nac) in the SDM, specific nodulation, $\mathrm{N}_{2}$ efficiency $\left(\mathrm{N}_{2} \mathrm{FE}\right), \mathrm{P}$ content in the SDM by the vanadate colorimetric method according to Malavolta et al. (23) and leghemoglobin content ( $\mathrm{LHb})$, measured by spectrophotometer $(540$ $\mathrm{nm}$ ) according to Wilson and Reisenauer (36). AMF spore density (15, 18), root colonization (16) and easily extractable glomalin (EEG) (37) were also evaluated. The experimental design was randomized blocks and treatments in a $5 \times 2 \times 2$ factorial setup. The first factor involved the presence or absence of nitrogen and inoculation with the
Bradyrhizobium sp. (BR 3267) and Bradyrhizobium sp. (EI - 6) strains separately and in combination (BR $3267+$ EI - 6) or no inoculation and no nitrogen - absolute control (AC) and without inoculation but with mineral nitrogen - nitrogen control (NC). The second and third factors were the absence or presence of AMF (Glomus etunicatum) and PGPB (Paenibacillus brasilensis - 24) or both, in all possible combinations with the first factor, resulting in a total of 20 treatments with 3 replicates.

The variance in the data was analyzed and contrasts were performed for each variable, with levels of significance of $5 \%$, evaluated by the F-test. The means were compared using the Tukey test $(\mathrm{p}<0.05)$.

\section{RESULTS AND DISCUSSION}

Statistical analysis by the F-test revealed significance for the isolated effects of the first factor (strains of Bradyrhizobium sp. BR 3267, EI - 6 inoculated separately and in combination [BR $3267+$ EI 6], AC and NC), the second factor (presence and absence of inoculation with $G$. etunicatum) and the third factor (presence and absence of inoculation with $P$. brasilensis - 24). Only the SDM of the cowpea plants showed interaction between factors 1 and 2 .

The cowpea plants inoculated with Bradyrhizobium sp. showed significant differences $(\mathrm{p}<0.05)$ for the variables SDM, Nac and EEG in soil (Table 1). The results showed that inoculation of cowpea plants with strains of Bradyrhizobium sp., applied either separately or in mixture, resulted in an SDM similar to the NC. The treatment with a mixture of strains (BR $3267+\mathrm{EI}-6$ ) provided an increase in Nac when compared to the AC. Inoculation with Glomus etunicatum did not favor the production of glomalin, obtaining a lower mean $(0.46$ mg glomalin per gram of aggregates).

Table 1. Shoot dry matter (SDM), nitrogen accumulation (Nac.), easily extractable glomalin (EEG) from soil and root colonization in treatments with strains of Bradyrhizobium sp. BR 3267 and EI - 6 inoculated separately and in combination (BR $3267+$ EI - 6), without inoculation and without nitrogen - absolute control (AC) and without inoculation and with mineral nitrogen - nitrogen control (NC)

\begin{tabular}{|c|c|c|c|c|}
\hline & $\begin{array}{l}\text { SDM } \\
\left(\text { g pot }^{-1}\right)\end{array}$ & $\begin{array}{l}\text { Nac } \\
\left(\text { mg N pot }^{-1}\right)\end{array}$ & $\begin{array}{l}\text { EEG } \\
\left(\mathrm{mg} \mathrm{g}^{-1} \text { aggregate }\right)\end{array}$ & $\begin{array}{l}\text { Root colonization } \\
(\%)\end{array}$ \\
\hline $\mathrm{NC}$ & $7.80 \mathrm{a}$ & $234.53 \mathrm{a}$ & $0.64 \mathrm{a}$ & $80.20 \mathrm{a}$ \\
\hline BR $3267+E I-6$ & $7.73 \mathrm{a}$ & $227.49 \mathrm{ab}$ & $0.51 \mathrm{ab}$ & $81.20 \mathrm{a}$ \\
\hline BR 3267 & $7.72 \mathrm{a}$ & $202.78 \mathrm{bc}$ & $0.48 \mathrm{ab}$ & $91.00 \mathrm{a}$ \\
\hline $\mathrm{EI}-6$ & $7.40 \mathrm{ab}$ & $212.62 \mathrm{abc}$ & $0.46 \mathrm{~b}$ & $81.60 \mathrm{a}$ \\
\hline $\mathrm{AC}$ & $6.62 \mathrm{~b}$ & $193.47 \mathrm{c}$ & $0.57 \mathrm{ab}$ & $81.00 \mathrm{a}$ \\
\hline$\% \mathrm{CV}$ & 9.92 & 10.29 & 28.81 & 17.97 \\
\hline
\end{tabular}


In assessing the effect of the inoculation of cowpea plants with $G$. etunicatum associated with different treatments, we found that presence of the fungi provided a higher mean for SDM treatments than those inoculated only with rhizobia EI - 6 alone or in mixture (BR $3267+\mathrm{EI}-6)$. These results corroborate those found by Jesus et al. (19), who obtained significant differences $(\mathrm{p}<0.05)$ when testing the coinoculation of rhizobia and AMF on the leguminous caiman tree Piptadenia gonoacantha. The absolute control was also aided by the presence of the fungus (Table 2). The effect of mycorrhizal association and the symbiosis with Bradyrhizobium sp. can be autocatalytic and synergistic because the biological processes can increase the photosynthetic rate of the microsymbiont. These processes can reduce the risk of the photosynthate drain that is caused by microsymbionts, which can cause reduction in crop yield (24). According Bonfante and Anca (3), dual inoculation is capable of reducing the costs of nitrogen and phosphate fertilizers. It can also give plants a greater ability to absorb nutrients, leading to an increase in productivity.

Table 2. Shoot dry matter (SDM) of cowpea plants inoculated with strains of Bradyrhizobium sp. BR 3267, EI - 6 separately and in mixture (BR 3267 + EI - 6), without inoculation and without nitrogen - absolute control (AC) and without inoculation and with mineral nitrogen - nitrogen control (NC), inoculated (I) or non-inoculated (NI) with Glomus etunicatum.

\begin{tabular}{lllcll}
\hline & \multicolumn{5}{c}{ SDM (g pot $\mathbf{~}^{-\mathbf{1}}$} \\
\cline { 2 - 7 } & BR 3267 & EI - 6 & BR 3267 + EI - 6 & AC & NC \\
\hline I & $7.85 \mathrm{a}$ & $7.86 \mathrm{a}$ & $8.28 \mathrm{a}$ & $7.75 \mathrm{a}$ & $8.21 \mathrm{a}$ \\
NI & $7.60 \mathrm{a}$ & $6.95 \mathrm{~b}$ & $7.17 \mathrm{~b}$ & $5.49 \mathrm{~b}$ & $7.40 \mathrm{a}$ \\
\hline$\% \mathrm{CV}$ & 9.92 & 9.92 & 9.92 & 9.92 & 9.92 \\
\hline
\end{tabular}

In each column, means (6 replicates) followed by the same letter do not differ statistically from each other at $\mathrm{p}<0.05$ according to the Tukey test.

Regardless of the treatment, the inoculation with $G$. etunicatum favored cowpea growth according to the variables SDM, RDM and SDM/RDM ratio, as well as Nac, $\mathrm{N}_{2} \mathrm{FE}$ and number of glomerospores in the soil. However, the plant height over time (10, 20, 30 and 40 days), root length and root colonization by AMF and EEG did not differ significantly ( $p$ $<0.05$ ) for the treatments inoculated or not inoculated with $G$. etunicatum (Table 3). The short period of time in which we evaluated these factors could have influenced the results of plant growth, such as plant height and root length. Additionally, the content of glomalin, found mainly in the mycelium and the wall of the AMF spores, is involved in the processes of soil aggregation and is considered a bioindicator of the abundance of extracellular production of mycelium in the soil (31). Finally, the high degree of colonization (80 to $100 \%$ ) reveals the infective potential of both the native and AMF isolates with which the plants were inoculated. The cowpea crop probably had not completed its life cycle, because the sporulation of AMF occurs more at the end of the plant cycle. The highest number of glomerospores was found in the soil of plants inoculated with $G$ etunicatum, due to the introduction of these fungi in their respective treatments. Bever et al. (1) mentioned that the host plant can be one of the main factors regulating the composition and structure of $\mathrm{AMF}$ communities, as each development phase (spore germination, hyphae growth, root colonization and sporulation) are influenced by the roots of plants. According to Bressan et al. (5), these factors are also influenced by the concentration of nutrients in the substrate.

The SDM level and SDM/RDM ratio were higher for the treatment inoculated with G. etunicatum, while the RDM was higher when plants were not inoculated. This fact can be explained by the increased contribution of mycelia extension in capturing the nutrients needed by plants and transferring them 
to the shoots. This result is in agreement with Tylka et al. (33), who showed that the presence of AMF increases SDM. The treatments with the presence and absence of G. etunicatum did not differ in NDM or LHb. In a comparable system, Mergulhão et al. (24) tested G. etunicatum and rhizobia co-inoculation on Mimosa caesalpinifolia Benth. plants in sandy soil and also found no significant differences $(\mathrm{p}<0.05)$ in the NDM. The Nac and $\mathrm{N}_{2} \mathrm{FE}$ were higher in plants inoculated with $G$. etunicatum. Inoculated plants usually have higher metabolisms than nonmycorrhizal plants and are able to provide greater amounts of carbohydrates to the rhizobia, resulting in more efficient nodulation. Thus, the results show that inoculation with G. etunicatum, despite not having made a significant difference in the NDM and LHb, increased nitrogen accumulation in the SDM and improved the $\mathrm{N}_{2}$ efficiency in cowpea plants. These results suggest that AMF can affect $\mathrm{N}$ acquisition by rhizobia and consequently increase symbiotic efficiency.

Table 3. Plant height at 10, 20, 30 and 40 days; root length (RL), shoot dry matter (SDM), root dry matter (RDM), SDM/RDM ratio, nodule dry matter (NDM), nitrogen accumulation (Nac.), $\mathrm{N}$ content, $\mathrm{N}_{2}$ efficiency $\left(\mathrm{N}_{2} \mathrm{FE}\right)$, leghemoglobin (LHb) and phosphorus content (P) in the cowpea plants, number of glomerospores, root colonization (\%) and easily extractable glomalin (EEG) in soil inoculated (I) or not inoculated (NI) with Glomus etunicatum.

\begin{tabular}{|c|c|c|c|c|c|}
\hline & \multicolumn{5}{|c|}{ Plant height $(\mathrm{cm})$} \\
\hline & $10 \mathrm{~d}$ & $20 \mathrm{~d}$ & & $30 \mathrm{~d}$ & $40 \mathrm{~d}$ \\
\hline I & $18.80 \mathrm{a}$ & $28.56 \mathrm{a}$ & & $54.03 \mathrm{a}$ & $148.60 \mathrm{a}$ \\
\hline NI & $18.73 \mathrm{a}$ & $28.00 \mathrm{a}$ & & $47.23 \mathrm{a}$ & $143.46 \mathrm{a}$ \\
\hline$\% \mathrm{CV}$ & 8.98 & 8.42 & & 33.20 & 18.40 \\
\hline & SDM & RDM & SDM/ RDM & $\mathbf{R L}$ & NDM \\
\hline I & $7.99 \mathrm{a}$ & $1.90 \mathrm{~b}$ & $4.31 \mathrm{a}$ & $42.90 \mathrm{a}$ & $194.06 \mathrm{a}$ \\
\hline NI & $6.92 \mathrm{~b}$ & $2.30 \mathrm{a}$ & $3.19 \mathrm{~b}$ & $42.20 \mathrm{a}$ & $183.33 \mathrm{a}$ \\
\hline$\% \mathrm{CV}$ & 9.92 & 33.54 & 23.84 & 19.82 & 18.29 \\
\hline & $\mathbf{N}$ ac. & N Cont & & $\mathbf{N}_{2} \mathbf{F E}$ & LHb \\
\hline I & $231.22 \mathrm{a}$ & $29.28 \mathrm{a}$ & & $1.22 \mathrm{a}$ & $0.50 \mathrm{a}$ \\
\hline NI & $197.09 \mathrm{~b}$ & $29.34 \mathrm{a}$ & & $1.10 \mathrm{~b}$ & $0.47 \mathrm{a}$ \\
\hline$\% \mathrm{CV}$ & 10.29 & 11.92 & & 17.38 & 24.25 \\
\hline & P Content & Glomero & & EEG & Root colonization $(\%)$ \\
\hline $\mathrm{I}$ & $1.47 \mathrm{a}$ & $213.40 \mathrm{a}$ & & $0.54 \mathrm{a}$ & $81.04 \mathrm{a}$ \\
\hline NI & $1.39 \mathrm{a}$ & $155.00 \mathrm{~b}$ & & $0.53 \mathrm{a}$ & $76.32 \mathrm{a}$ \\
\hline$\% \mathrm{CV}$ & 17.41 & 17.03 & 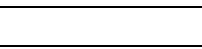 & 28.81 & 28.60 \\
\hline
\end{tabular}

The inoculation with $G$. etunicatum increased the $\mathrm{P}$ content of the SDM, but this result was not significant ( $\mathrm{p}$ $<0.05$ ) by the Tukey test. A decrease or increase in phosphorus concentrations is reported by different researchers, according to genus, variety and plant cultivar. Bhivare and Nimbalkar (2) observed increases in $\mathrm{P}$ concentrations in the shoots of the bean cv. vaghia. Joshi (20) reported a reduction of this element in Cajanus cajan (L.) Huth, while Flores-Aylas et al. (14) observed no significant difference $(\mathrm{p}<0.05)$ in Schinus terebenthifolius Raddi and Trema micrantha (L.) Blume.

In an attempt to keep the micro and macro biota and their interactions closer to their native state, we chose to work with 
the inoculation of microorganisms using unsterilized soil and in greenhouse conditions. Competition between AMF species, in terms of their ability to colonize roots, can also be influenced by environmental conditions (7). Experiments involving soils with native AMF on a single host will probably better reflect those processes that naturally occur (8). Interspecific competition has been measured as a function of sporulation differentiated by these fungi and the formation of entry points into roots being colonized.
Despite these interactions, a combination of fungal isolates (native + tested) has been shown to provide a greater benefit in growth than when only a single fungus colonizes the roots of the plant (9).

The co-inoculation with Paenibacillus brasilensis - 24 favored cowpea development (Table 4). A significant difference was observed $(p<0.05)$ by the Tukey test for the variables plant height at 10, 20, 30 and 40 days, SDM, RDM, SDM/RDM ratio, NDM, Nac and $\mathrm{N}$ content in cowpea plants.

Table 4. Plant height at 10, 20, 30 and 40 days, shoot (SDM), root (RDM) and nodule dry matter (NDM), SDM/RDM ratio, root length (RL), nitrogen accumulation ( $\mathrm{N}$ ac.), $\mathrm{N}$ content, $\mathrm{N}_{2}$ efficiency $\left(\mathrm{N}_{2} \mathrm{FE}\right)$, leghemoglobin (LHb), phosphorus content (P) and mycorrhizal colonization (MC) in the cowpea plants and number of glomerospores, easily extractable glomalin (EEG) in soil inoculated (I) or not inoculated (NI) with Paenibacillus brasilensis - 24.

\begin{tabular}{|c|c|c|c|c|c|}
\hline & \multicolumn{5}{|c|}{ Plant height $(\mathrm{cm})$} \\
\hline & $10 \mathrm{~d}$ & $20 \mathrm{~d}$ & & $30 \mathrm{~d}$ & $40 \mathrm{~d}$ \\
\hline I & $19.40 \mathrm{a}$ & $30.00 \mathrm{a}$ & & $62.95 \mathrm{a}$ & $160.76 \mathrm{a}$ \\
\hline NI & $18.13 \mathrm{~b}$ & $26.56 \mathrm{~b}$ & & $38.31 \mathrm{~b}$ & $131.30 \mathrm{~b}$ \\
\hline$\% \mathrm{CV}$ & 8.98 & 8.42 & & 33.20 & 18.40 \\
\hline & SDM & RDM & SDM/RDM & RL & NDM \\
\hline I & $8.82 \mathrm{a}$ & $2.38 \mathrm{a}$ & $3.99 \mathrm{a}$ & $43.70 \mathrm{a}$ & $209.20 \mathrm{a}$ \\
\hline $\mathrm{NI}$ & $6.09 \mathrm{~b}$ & $1.82 \mathrm{~b}$ & $3.52 \mathrm{~b}$ & $41.50 \mathrm{a}$ & $168.20 \mathrm{~b}$ \\
\hline$\% \mathrm{CV}$ & 9.92 & 33.54 & 23.84 & 19.82 & 18.29 \\
\hline & $\mathbf{N}$ ac. & N Content & & $\mathbf{N}_{2} \mathbf{F E}$ & LHb \\
\hline I & $239.06 \mathrm{a}$ & $27.34 \mathrm{~b}$ & & $1.17 \mathrm{a}$ & $0.50 \mathrm{a}$ \\
\hline NI & $189.26 \mathrm{~b}$ & $31.29 \mathrm{a}$ & & $1.16 \mathrm{a}$ & $0.47 \mathrm{a}$ \\
\hline$\% \mathrm{CV}$ & 10.29 & 11.92 & & 17.38 & 24.25 \\
\hline & $\mathbf{P}$ & MC & & EEG & Glomerospores** \\
\hline I & $1.46 \mathrm{a}$ & $81.89 \mathrm{a}$ & & $0.51 \mathrm{a}$ & $189.80 \mathrm{a}$ \\
\hline $\mathrm{NI}$ & $1.40 \mathrm{a}$ & $78.11 \mathrm{a}$ & & $0.56 \mathrm{a}$ & $178.40 \mathrm{a}$ \\
\hline$\% \mathrm{CV}$ & 17.41 & 28.60 & & 28.21 & 17.03 \\
\hline
\end{tabular}

In each column, means (30 replicates) followed by the same letter do not differ statistically from each other at $\mathrm{p}<0.05$ according to the Tukey test.

* NFM = nodule fresh matter

** Original medium processed to $\sqrt{ }(\mathrm{x}+0)$.

The plant height over time (10, 20, 30 and 40 days) was higher for the treatments inoculated with P. brasilensis - 24 . Sivaramaiah et al. (27), studying inoculation with different strains of Bacillus sp. in Cicer arietinum L., noted that these bacteria stimulate shoot growth at 10 days of observation compared to the control. Shishido and Chanway (28) observed that growth promotion in silver firs (Abies sp.) resulting from the application of bacteria from the same ecosystem was low and being not therefore necessary to combine other isolates such as Pseudomonas with the fir ecotypes (Abies sp.) and soil types for effective promotion of seedling growth, confirming the non-specificity, as found in this work. Some authors emphasize the need for homogenous isolates or isolates adapted to the host, justified by a greater colonization capacity, lowering the risk of introducing exogenous organisms (21) and specificity between the host and isolated PGPR. 
The RL showed no difference between treatments coinoculated with or without $P$. brasilensis - 24, which probably occurred because the experimental unit (pot) was limited affecting the RL. However, the co-inoculated treatment provided greater mean RDM, assuming that the roots grew laterally. The $\mathrm{N}_{2} \mathrm{FE}, \mathrm{LHb}$ and $\mathrm{P}$ content showed no significant difference $(\mathrm{p}<0.05)$ provided by the co-inoculation of $P$. brasilensis - 24, although these variables presented the highest means. According to Triplett (32), the co-inoculation of rhizobia with other bacteria such as Bacillus, Azospirillum and Agrobacterium can promote symbiosis with legumes in many ways, highlighting the influence of increasing competitiveness of the rhizobia inoculated. The inoculation of P. brasilensis 24 showed no significant difference $(\mathrm{p}<0.05)$ in the number of glomerospores in the soil, root colonization or glomalin, thus not favoring the increase of these variables.

\section{CONCLUSIONS}

The use of microorganisms as key components to increase the availability of nutrients to plants has proved to have great practical importance for sustainable agriculture. In this study, the nitrogen from symbiosis was sufficient to supply the needs of cowpea plants while the $\mathrm{N}$ accumulated in the plants inoculated with a mixture of strains of Bradyrhizobium sp. (BR 3267+ EI 6) was higher compared to the single inoculation with the strain BR 3267. The dual inoculation with Bradyrhizobium sp. and Glomus etunicatum provided a greater accumulation of nitrogen in the plants. The inoculation with $G$. etunicatum increased the shoot dry matter more than the treatments inoculated only with native AMF from the soil. The dual inoculation with $G$. etunicatum and Paenibacillus brasilensis - 24 promoted greater growth of the cowpea plants.

\section{ACKNOWLEDGEMENTS}

We are grateful to the National Council for Scientific and Technological Development (CNPq), Brazil, for financial support.

\section{REFERENCES}

1. Bever, J.K.; Morton, J.B.; Antonovics, J.; Schultz, P.A. (1996). Hostdependent sporulation and species diversity of arbuscular mycorrhizal fungi in a mown granland. J. Ecol. 84, 71-82.

2. Bhivare ,V.N.; Nimbalkar, J.D. (1984). Salt effects on growth and mineral nutrition of french beans. Plant Soil 80, 91-98.

3. Bonfante, P.; Anca, I.A. (2009). Plants, Mycorrhizal fungi and bactéria: A network of interactions. Ann. Rev. Microbiol. 63, 363-383.

4. Bremner, J.M. (1965). Total nitrogen. In: Black, C.A. (ed.). Methods of Soil Analysis Chemical and Microbiological Properties, Part 2. American Society of Agronomy, Madison, p. 1149-1178.

5. Bressan, W. (2002). Factors affecting "in vitro" plant development and root colonization of sweet potato by Glomus etunicatum Becker \& Gerd. Braz. J. Microbiol. 33, 31-34.

6. Burity, H.A.; Lyra, M.C.C.P.; Souza, E.S.; Mergulhão, A.C.E.S.; Silva, M.L.R.B. (2000). Efetividade da inoculação com rizóbio e fungos micorrízicos arbusculares em mudas de sabiá submetidas a diferentes níveis de fósforo. Pesq. Agropecu. Bras. 35, 801-807.

7. Carrenho, R.; Silva, E.S.; Trufem, S.F.B.; Bononi, V.L.R. (2001). Successive cultivation of maize and agricultural practices on root colonization, number of spores and species of arbuscular mycorrhizal fungi. Braz. J. Microbiol. 32, 262-270.

8. Corrêa, A; Strasser, R.J.; Martins-Loça, M.A. (2006). Are mycorrhiza always beneficial? Plant and Soil 279, 65-73.

9. Daft, M.J.; Hogarth, B.G. (1983). Competitive interactions amongst four species of Glomus on maize and onion. T. Brit. Mycol. Soc. 80, 339-345.

10. Dakora, F.D. (2003). Defining new roles for plant and rhizobial molecules in sole and mixed plant cultures involving symbiotic legumes. New Phytol. 158, 39-49.

11. Empresa Brasileira de Pesquisa Agropecuária. (1999). Sistema brasileiro de classificação de solos, 1. Serviço Nacional de Levantamento e Conservação de Solos, Rio de Janeiro.

12. Figueiredo, M.V.B.; Burity, H.A.; Martinez, C.R.; Chanway, C.P. (2008). Alleviation of water stress effects in common bean (Phaseolus vulgaris L.) by co-inoculation Paenibacillus x Rhizobium tropici. Appl. Soil Ecology 40, 182-188.

13. Figueiredo, M.V.B.; Burity, H.A.; Martinez, C.R.; Chanway, C.P. (2007). Drought stress response on some key enzymes of cowpea (Vigna unguiculata L. Walp.) nodule metabolism. World J. Microbiol. Biotechnol. 23, 187-193.

14. Flores-Aylas, W.W.; Saggin-Junior, O.J.; Siqueira, J.O.; David, A.C. (2003). Efeito de Glomus etunicatum e fósforo no crescimento inicial de espécies arbóreas em semeadura direta. Pesq. Agropecu. Bras. 38, $257-$ 
266.

15. Gerdemann, J.W.; Nicolson, T.H. (1963). Spores of mycorrhizal Endogone species extracted from soil by wet sieving and decanting. T. Brit. Mycol. Soc. 46, 235-244.

16. Giovannetti, M.; Mosse, B. (1980). An evaluation of techniques for measuring vesicular arbuscular mycorrhizal infection in roots. New Phytol. 84, 489-500.

17. Hoagland, D.R.; Arnon, D.I. (1950). The water culture method of growing plants without soil. University California, Berkeley.

18. Jenkins, W.R. (1964). A rapid centrifugal-flotation technique for separating nematodes from soil. Plant Dis. Rep. 48, 692.

19. Jesus, E.C.; Schiavo, J.A.; Faria, S.M. (2005). Dependência de micorrizas para a nodulação de leguminosas arbóreas tropicais. Rev. Arvore 29, 545-552.

20. Joshi, S.S. (1984). Effect of salinity stress on organic and mineral constituents in the leaves of pigeonpea (Cajanus cajan L. var. C-11). Plant Soil 82, 69-76.

21. Khalid, A.; Arshad, M.; Zahir, Z.A. (2004). Screening plant growthpromoting rhizobacteria improving growth and yield of wheat. J. Appl. Microbiol. 96, 473-480.

22. Lima, S.T.L; Barreto, M.C.S; Araújo, J.M; Seldin, L; Burity, H.A; Figueiredo, M.V.B. (2010). Co-inoculation of Bacillus, Brevibacillus and/or Paenibacillus in the Bradyrhizobium-cowpea symbiosis: study of the synergism, Rev. Bras. Ciên. Solo (in press).

23. Malavolta, E.; Vitti, G.C.B.; Oliveira, A.S. (1997). Avaliação do estado nutricional das plantas. Princípios e Aplicações. $2^{\mathrm{a}}$ ed. Potafos, Piracicaba.

24. Mergulhão, A.C.E.S.; Silva M.L.R.B.; Burity, H.A.; Stamford, N.P. (2001). Influência da dupla inoculação rizóbio e fungos micorrizasarbusculares em plantas de sabiá sob solos de diferentes texturas. Rev. Ecossistema 26, 42-47.

25. Rumjanek, N.G.; Xavier, G.R.; Martins, L.M.V.; Morgado, L.B.; Neves, M.C.P. (2006). Feijão caupi tem uma nova estirpe de rizóbio, BR3267, recomendada como inoculante. Boletim de Pesquisa e Desenvolvimento da Embrapa 15, 1-16.
26. Selosse M.A, Baudoin E, Vandenkoornhuyse, P (2004) Symbiotic microorganisms, a key for ecological success and protection of plants. $C$. R. Biologies 327, 639-648.

27. Sivaramaiah N.; Malik, D.K.; Sindhu, S.S. (2007). Improvement in symbiotic efficiency of chickpea (Cicer arietinum) by coinoculation of Bacillus strains with Mesorhizobium sp. Cicer. Indian J. Microbiol. 47, 51-56.

28. Shishido, M.; Chanway, C.P. (1999). Spruce growth response specificity after treatment with plant growth promoting Pseudomonas. Can. J. Botany 77, 22-31.

29. Smith, S.E.; Read, D. (2008). Mycorrhizal Symbiosis. $3^{\mathrm{a}}$ ed. Academic Press, London.

30. Souchie, E.L.; Azcón, R.; Barea, J.M.; Saggin-Júnior, O.J.; Silva, E.M.R. (2007). Indolacetic acid production by P-solubilizing microorganisms and interaction with arbuscular mycorrhizal fungi. Acta Sci. Biol. Sci. 29:315-320.

31. Steinberg, P.O.; Rillig, M.C. (2003). Differential decomposition of arbuscular mycorrhizal fungal hyphae and glomalin. Soil Biol Biochem 35, 191-194.

32. Triplett, E.W. (1990). The molecular genetics of nodulation competitiveness in Rhizobium and Bradyrhizobium. Mol. Plant. Microbe In. 3, 199-206.

33. Tylka, G.L.; Hussey, R.S.; Roncadori, R.W. (1991). Interactions of vesicular-arbuscular mycorrhyzal fungi, phophorus, and Heterodera glycines on soybean. J. Nematol. 23, 122-133.

34. Vessey, J.K. (2003) Plant growth-promoting rhizobacteria as biofertilizers. Plant Soil 255, 571-586.

35. Vincent, J.M. (1970). A manual for the pratical study of root-nodulebacteria. Oxford, Blackwells Scientific Publications.

36. Wilson, D.O.; Reisenauer, H.M. (1963). Determination of leghemoblobin in legume nodules. Anal Biochem 6, 27-30.

37. Wright, S.F.; Upadhyaya, A. (1996). Extraction of an abundant and unusual protein from soil and comparison with hyphal protein of arbuscular mycorrhizal fungi. Soil Sci. 161, 575-586. 